\title{
Restriction endonuclease analysis of RAPD-PCR amplicons derived from Shiga-like toxin-producing Escherichia coli 0157 isolates
}

\author{
KATIE L. HOPKINS and ANTHONY C. HILTON* \\ Department of Biosciences, University of Birmingham, Edgbaston, Birmingham B15 2TT and * Life and Health \\ Sciences, Aston University, Aston Triangle, Birmingham B4 7ET.
}

\begin{abstract}
Shiga-like toxin-producing Escherichia coli 0157 isolates were characterised by random amplification of polymorphic DNA by PCR (RAPD-PCR) analysis developed to allow robust epidemiological typing of $E$. coli. Amplification with primer 1247 or 1290 generated a reproducible profile, but was not capable of distinguishing sufficiently between epidemiologically unrelated strains. Subsequent digestion of the amplicons with selected restriction endonucleases improved the discriminatory ability of this method for strains showing limited differentiation following RAPD-PCR analysis alone. Restriction endonuclease analysis of RAPD-PCR fragments generated from closely related strains has the potential to provide additional discriminatory information without loss of specificity.
\end{abstract}

\section{Introduction}

Shiga-like toxin-producing Escherichia coli (STEC) O157 was first linked to cases of bloody diarrhoea (haemorrhagic colitis) following two outbreaks in Oregon and Michigan in 1982 [1]. Similar cases had occurred previously in the USA and Japan but no aetiological agent was identified. In recent years the incidence of STEC 0157 disease has been increasing, partly because of increased testing of stool samples sent to laboratories and improved isolation methods, but also as a result of a real increase in numbers. In 1994, 411 cases were reported in England and Wales, rising to 890 in 1998 [2]. Infection is often associated with the consumption of undercooked beef products (minced beef in particular); however, STEC O157 has also been isolated from other meats and vegetables [3]. Outbreaks often occur in settings such as day-care centres, schools and hospitals; person-to-person spread in such institutions may occur via the faecal-oral route as a result of the low infective dose and the presence of susceptible people [4]. Infection may also occur through direct or indirect contact with infected cattle and cattle faeces, e.g., during farm visits [5].

Received 4 Feb. 2000; revised version received 28 May 2000; accepted 13 June 2000.

Corresponding author: Dr A.C. Hilton (e-mail: A.C.Hilton@ aston.ac.uk).
The ability to differentiate between strains of STEC O157 is complicated by the clonal nature of this group. Natural populations of $E$. coli consist of a number of stable cell lines between which there is relatively little recombination of chromosomal genes. Traditional typing methods such as biochemical profiling [6], plasmid profiling [7], verocytotoxin typing [7], phage typing [8], ribotyping [9] and pulsed-field gel electrophoresis (PFGE) [10] have had limited success in intraserogroup differentiation. As a consequence, there is a need to improve subtyping methods, with particular emphasis on the development of molecular methods to target the often minimal amount of variation observed between strains. Current methods are variable in their speed, technical complexity, cost and ability to discriminate reliably between STEC O157 [11]. To be able to trace reliably the source and mode of transmission of an outbreak, an epidemiological typing method must be able to discriminate reproducibly between different strains and identify identical strains. The potentially very severe sequelae arising from STEC O157 infection, including renal failure and death, mean that quick and effective epidemiological methods are required to trace the source and route of transmission of an outbreak.

Random amplification of polymorphic DNA by PCR (RAPD-PCR) analysis [12, 13] is a molecular typing method which is finding increasing acceptance. A single, short (8-10 bp) primer of arbitrary sequence binds at complementary and partially mismatched sites 
to produce a useful strain-specific array of amplicons characteristic of the template DNA. Any differences between the DNA sequences of two strains can add or remove binding sites or alter the distance between them, leading to changes in the amplicon profile. However, differences may exist undetected in the DNA sequence between two priming sites of an amplicon if they do not affect primer binding or amplicon length [14]. Previous studies in which RAPD-PCR was used to subtype strains of STEC O157 have shown RAPDPCR to be of considerable use in epidemiological studies and the technique compared favourably against selected typing methods [11].

In this study a robust RAPD-PCR protocol was applied to discriminate between strains of STEC O157 by RAPD-PCR analysis. The amplicons produced were subjected to restriction endonuclease analysis (REA) with a number of restriction endonucleases to try to increase the inter-strain discriminatory capacity by targeting previously undetected polymorphisms in the DNA sequences.

\section{Materials and methods}

\section{Bacterial strains}

Clinical Shiga-like toxin-producing Escherichia coli O157 isolates were received from the Birmingham Public Health Laboratory and genomic DNA was prepared as described previously [15]. The DNA was checked for purity and concentration and diluted to 10 $\mathrm{ng} / \mu \mathrm{l}$ with sterile distilled water. Isolates were chosen at random from an available culture collection of isolates from cases of human gastrointestinal tract illness (Table 1), with the exception of isolates 908820 and 908821, which were well-characterised isolates known to belong to an outbreak and were used as a control.

\section{$R A P D$ reactions}

The PCR was performed in a $25-\mu$ l volume with $10 \times$ PCR buffer (100 mM Tris- $\mathrm{HCl}, 35 \mathrm{mM} \mathrm{MgCl}_{2}, 250 \mathrm{mM}$
$\mathrm{KCl}, \mathrm{pH} 8.3) 2.5 \mu \mathrm{l}, 10 \mathrm{~mm}$ dNTPs (Bioline, London) $0.5 \mu \mathrm{l}, 100 \mathrm{~mm}$ primer (1247: 5'-AAG-AGC-CCG-T-3' and 1290: 5'-GTG-GAT-GCG-A-3', [16]) $0.6 \mu \mathrm{l}$, Taq DNA polymerase (Gibco-BRL, Paisley) 1.25 units, $\mathrm{H}_{2} \mathrm{O} 19.15 \mu \mathrm{l}$ and template DNA $2 \mu \mathrm{l}$. Reactions were amplified in a Progene thermal cycler (Techne, Cambridge) as follows: one cycle of $4.5 \mathrm{~min}$ at $94^{\circ} \mathrm{C}$, followed by five low stringency cycles of $30 \mathrm{~s}$ at $94^{\circ} \mathrm{C}$, $1 \mathrm{~min}$ at $22^{\circ} \mathrm{C}, 2 \mathrm{~min}$ at $72^{\circ} \mathrm{C}$, followed by 35 high stringency cycles of $30 \mathrm{~s}$ at $94^{\circ} \mathrm{C}, 30 \mathrm{~s}$ at $28^{\circ} \mathrm{C}, 3 \mathrm{~min}$ at $72^{\circ} \mathrm{C}$. Amplification was concluded with $5 \mathrm{~min}$ at $72^{\circ} \mathrm{C}$ and the reaction products were stored at $-20^{\circ} \mathrm{C}$ before restriction endonuclease analysis.

\section{Restriction endonuclease analysis}

Restriction endonuclease digestions were performed as described previously [14]. To select restriction endonucleases capable of cutting the RAPD-PCR amplicons, DNA was amplified from a single STEC O157 isolate (908873) by primers 1290 and 1247 alone. The resulting DNA was digested with endonucleases $P v u \mathrm{I}$, $B g l \mathrm{II}, E c o$ RI, SmaI and HindIII (Gibco-BRL) and Bsp1431 (Helena Biosciences, Tyne and Wear).

\section{Profile analysis}

Samples $(10 \mu \mathrm{l})$ of each digest were loaded on to an agarose $1.5 \%$ gel containing ethidium bromide $0.5 \mu \mathrm{g}$ / $\mathrm{ml}$ and electrophoresed in $1 \times$ TBE buffer, except digests with Bsp 1431 which were electrophoresed in polyacrylamide $8 \%$ gels. The resulting separated DNA fragments were visualised with an UV $(300 \mathrm{~nm})$ transilluminator and the fragment pattern in each gel was recorded with an IS500 digital imaging system (Flowgen, Kent). Digitally captured profiles were analysed with GelCompar software (Version 4.0, Applied Maths, Belgium) with the band matching coefficient of Dice, and Ward clustering to determine profile relatedness. All visible fragments in the range $\sim 300 \mathrm{bp}-4 \mathrm{~kb}$ were included in the profile analysis.

Table 1. Strains of STEC O157 typed by RAPD-PCR, followed by restriction endonuclease analysis

\begin{tabular}{|c|c|c|c|c|c|c|}
\hline $\begin{array}{l}\text { Strain } \\
\text { no. }\end{array}$ & Symptoms & $\begin{array}{l}\text { Age of } \\
\text { patient (years) }\end{array}$ & $\begin{array}{l}\text { Source of } \\
\text { isolate }\end{array}$ & $\begin{array}{c}\text { Date of } \\
\text { isolation } \\
(\mathrm{d} / \mathrm{m} / \mathrm{y})\end{array}$ & $\begin{array}{l}\text { Phage } \\
\text { type }\end{array}$ & $\begin{array}{l}\text { Toxin } \\
\text { type }\end{array}$ \\
\hline 908820 & HUS & Sandwell & 5 & $21 / 8 / 97$ & PT2 & SLT2 \\
\hline 908821 & HUS & Sandwell & 4 & $22 / 8 / 97$ & PT2 & SLT2 \\
\hline 909016 & HUS & Birmingham & 15 & $24 / 8 / 97$ & PT2 & SLT2 \\
\hline 908873 & HUS & Birmingham & 55 & $28 / 8 / 97$ & PT8 & ND \\
\hline 910061 & HUS & Birmingham & 10 & $29 / 8 / 97$ & RDNC & ND \\
\hline 914319 & $\mathrm{HC}$ & Birmingham & 2 & $9 / 12 / 97$ & PT4 & SLT2 \\
\hline 914092 & Asymptomatic & Birmingham & 64 & $2 / 12 / 97$ & PT21 & SLT1\&2 \\
\hline 908212 & $\mathrm{HC}$ & Birmingham & 22 & $14 / 8 / 98$ & PT1 & SLT2 \\
\hline 910833 & $\mathrm{HC}$ & Birmingham & 52 & $29 / 10 / 98$ & PT34 & SLT negative \\
\hline 910634 & $\mathrm{HC}$ & Birmingham & 61 & $23 / 10 / 98$ & PT32 & SLT2 \\
\hline
\end{tabular}

HC, haemorrhagic colitis; HUS, haemolytic uraemic syndrome; RDNC, reacts, does not conform; SLT, Shiga-like toxin; ND, not determined; PT, phage type. 


\section{Results}

In this study, RAPD-PCR and REA were used together to subtype human STEC O157 strains. The described RAPD-PCR protocol is the result of systematic optimisation of reaction and cycling conditions to achieve reproducible profiles suitable for epidemiological analysis [17].

The RAPD-PCR analysis produced useful arrays of 8 22 bands with 100\% typability. Fragment size ranged from 0.3 to $4 \mathrm{~kb}$. Analysis with either primer 1290 or 1247 gave limited discrimination when RAPD-PCR was used alone. Nine epidemiologically unrelated clinical isolates of STEC O157 were shown to share c. $94 \%$ similarity when typed with primer 1290 . The use of a second primer (1247) did not increase the discrimination between these isolates, again clustering with $94 \%$ similarity (data not shown).

During preliminary work to determine suitable restriction endonucleases, only $P v u \mathrm{I}, B g l \mathrm{II}, E c o R \mathrm{I}$ and Sma I produced noticeable differences in the band profiles when compared with the uncut profiles; therefore, these were taken forward for further analysis. The range of fragment sizes did not change considerably when digested and uncut DNA were compared. The frequent-cutting enzyme Bsp 1431 produced bands that were difficult to resolve even in high percentage polyacrylamide gels and did not provide any additional discriminatory power.

The nine random clinical STEC O157 isolates were RAPD-PCR typed with primer 1290 or 1247 and the recovered DNA was digested with $P v u \mathrm{I}, B g l \mathrm{II}, E c o R \mathrm{I}$ or $S m a$ I. Strains were typed in duplicate over different time periods and comparison of the resulting products demonstrated the reproducibility of the combined RAPD-PCR/REA method. After digestion with $B g l \mathrm{II}$ or $P v u \mathrm{I}$, all isolates remained clustered at $c$. $94 \%$; however, new polymorphisms were detected by comparison of digested DNA profiles with uncut profiles. SmaI and EcoRI were more discriminatory and clustered the isolates at c. $90 \%$. Digestion of fragments with $B g l$ II resulted in profiles with fewer fragments than the uncut profiles, suggesting co-migration of similar sized fragments or generation of fragments that were too small to be resolved on the agarose gel. Five of the isolates (nos. 910061, 914319, 914092, 908212 and 910634) were no better differentiated after REA than with RAPD-PCR alone. However, isolates 908873 and 910833, which were identical by RAPD-PCR typing with primer 1290 and differed by only one band when typed with primer 1247, were differentiated further when either $B g l \mathrm{II}$ or $P v u \mathrm{I}$ were used (Fig. 1). Isolates 909016 and 908821 were differentiated only after EcoRI and Sma I digestion of DNA amplified with primer 1247. In contrast, isolates 908820 and 908821 were identical in RAPD-PCR with either primer and following digestion with all of the enzymes (Fig. 2).

\section{Discussion}

The ability to differentiate between strains of STEC O157, which are responsible for the majority of cases of enterohaemorrhagic disease, is complicated by the clonal nature of the group. Typing methods such as biochemical typing, plasmid profiling, verocytotoxin typing, phage typing and ribotyping are often insufficiently discriminatory, as they may be limited to the number of types that can be described, or 'interrogate' only highly conserved regions of the chromosome. In practice, a number of phenotypic and DNA-based techniques may be used in combination, depending on the amount of discrimination required and the time and resources available. Molecular methods such as PFGE, RAPD-PCR and REA examine the whole chromosome and, therefore, may be more likely to target the often minimal amount of variation observed between strains. However, in highly clonal organisms such as STEC 0157, this can be very difficult; while the DNA fragments produced by any of these three methods may be of the same mol. wt between two strains, they may not necessarily be of the same sequence. In this study the combined methods of RAPD-PCR and REA, as described previously [14], were applied to STEC O157 in an attempt to differentiate further between fragments of the same apparent mol. wt following agarose gel electrophoresis.

The highly clonal nature of STEC O157 is illustrated here by the tight clustering of the isolates, sharing 90\% similarity even after restriction endonuclease digestion. There appears to be a limited number of pathogenic clones which are widespread and responsible for most cases of disease, supported by previous work studying the population genetics of STEC O157:H7 strains by multi-enzyme electrophoresis [18].

The use of a frequent-cutting endonuclease did not provide increased discrimination. This was also noted by Hilton and Penn [14].

When the objective is to improve existing typing methods, care should be taken not to become excessively discriminatory; it is as important to identify identical isolates as it is those that are different. Isolates 908820 and 908821 were identical by phage typing, Shiga-like toxin typing and RAPD-PCR analysis with either primer 1290 or 1247 , and subsequent digestion with each of the four enzymes confirmed the relatedness of these isolates. The two isolates were part of an outbreak and these results illustrate that, while restriction endonuclease analysis of RAPD-PCR amplicons is highly discriminatory, it is still able to group similar and identical isolates together reproducibly. Isolate 909016 is an epidemiologically unrelated isolate with the same phage type and Shiga-like toxin type as isolates 908820 and 908821 , but could be differentiated from them by RAPD-PCR, thus demonstrating that RAPD-PCR, when used alone, offers a higher level of 
a

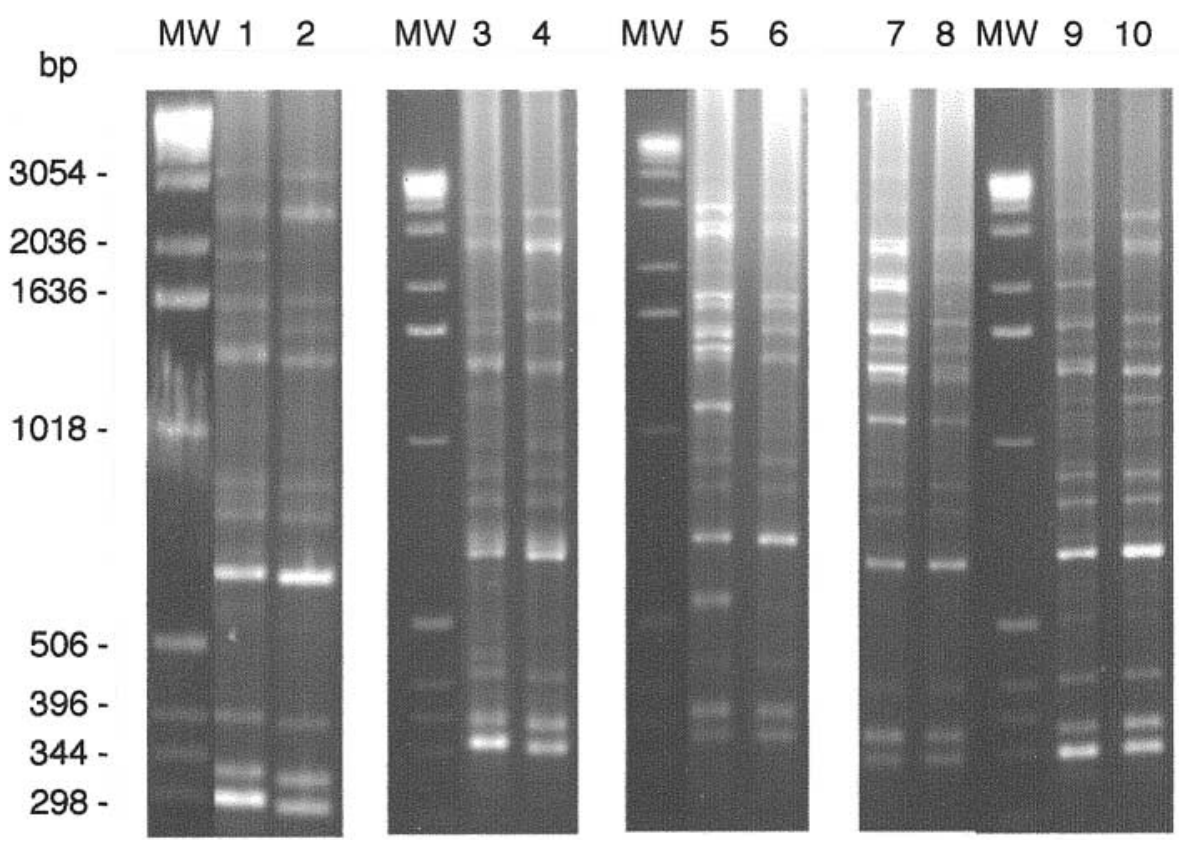

b

$\begin{array}{llllllll}5 & 6 & \text { MW } & 7 & 8 & \text { MW } & 9 & 10\end{array}$
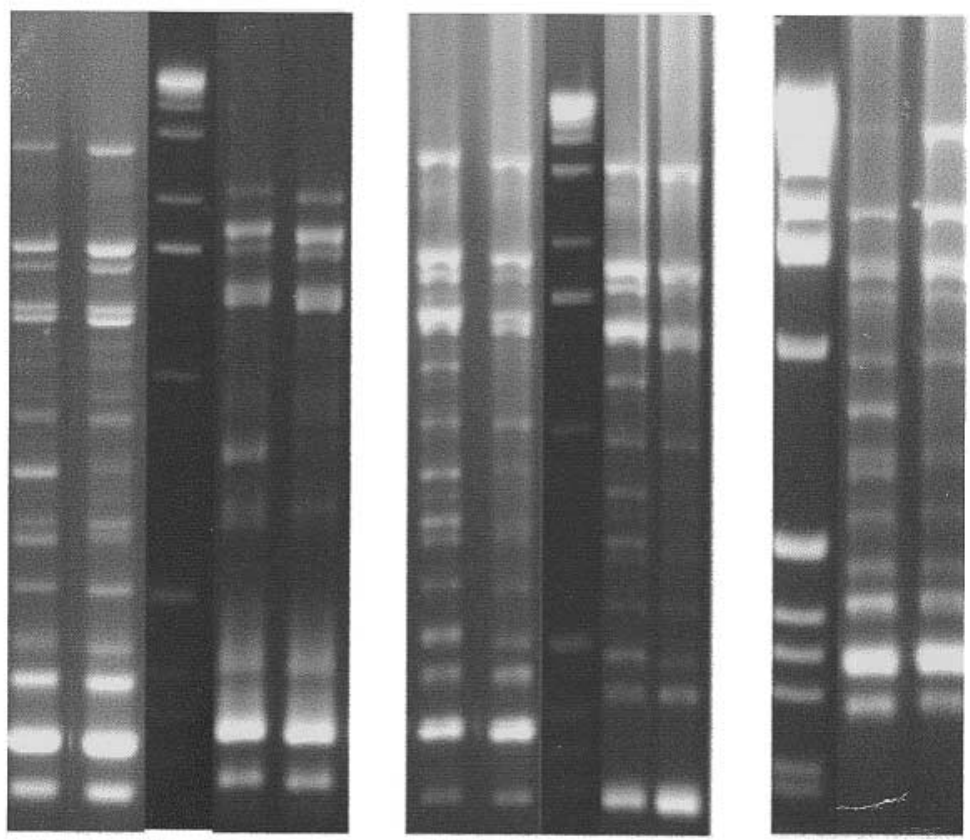

Fig. 1. Restriction endonuclease analysis of isolates 908873 and 910833 after RAPD-PCR analysis with (a) primer 1247, (b) primer 1290. Lanes: 1, uncut 908873; 2, uncut 910833; 3, BglII 908873; 4, BglII 910833; 5, EcoRI 908873; 6, EcoRI 910833; 7, Sma I 908873; 8, SmaI 910833; 9, PvuI 908873; 10, PvuI 910833; MW, 1-kb DNA mol. wt ladder (Gibco-BRL).

discrimination than phage typing and Shiga-like toxin typing combined.

In contrast, isolate pairs 908873 and 910833, and 909016 and 908821 , demonstrate that intra-fragment sequence variation can exist between amplicons of the same mol. wt that may be targeted by restriction endonuclease analysis. However, this method could not further distinguish between isolates of Salmonella enterica serotypes Enteritidis PT4 and Typhimurium DT104 [14], which may have been because these serotypes represent a more highly clonal group than STEC 0157.

The discriminatory capacity of RAPD-PCR and the quality of genetic fingerprints produced can depend on 
a

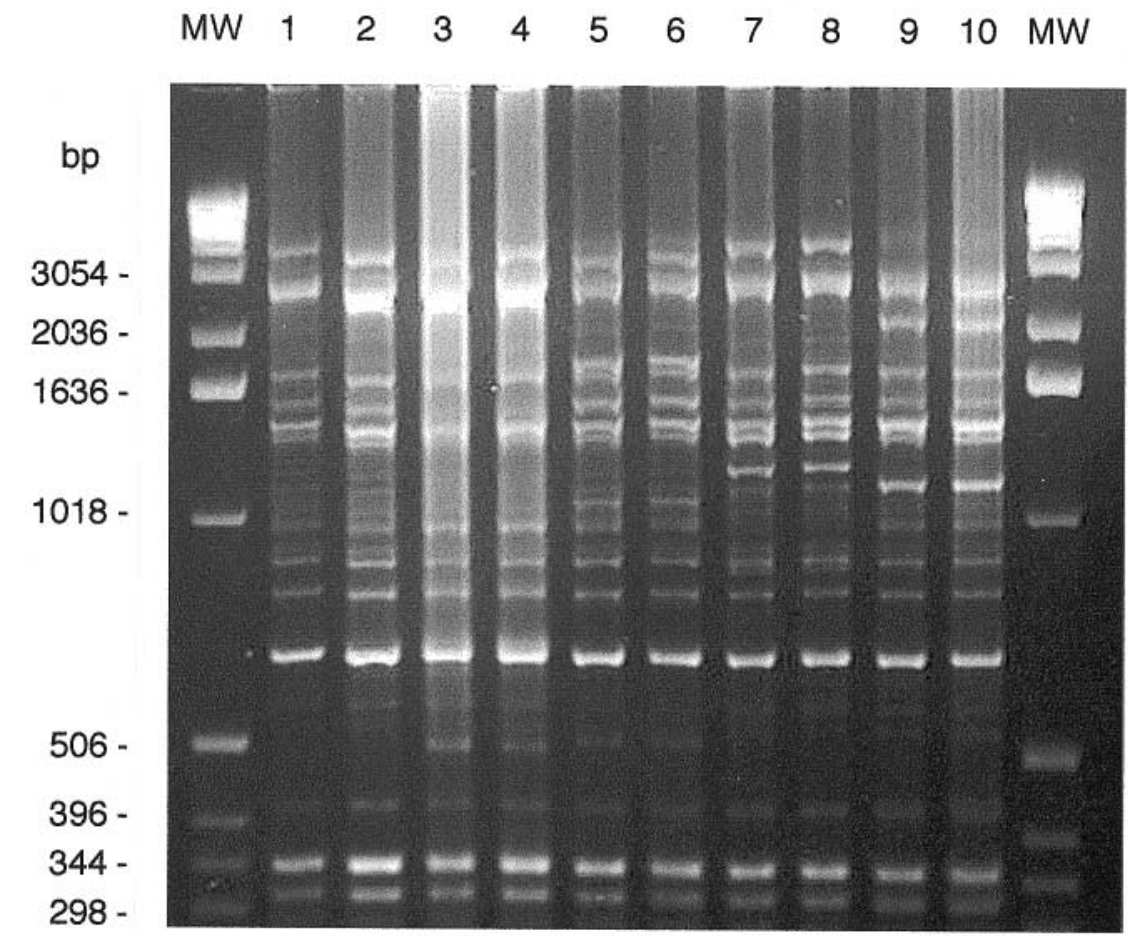

b

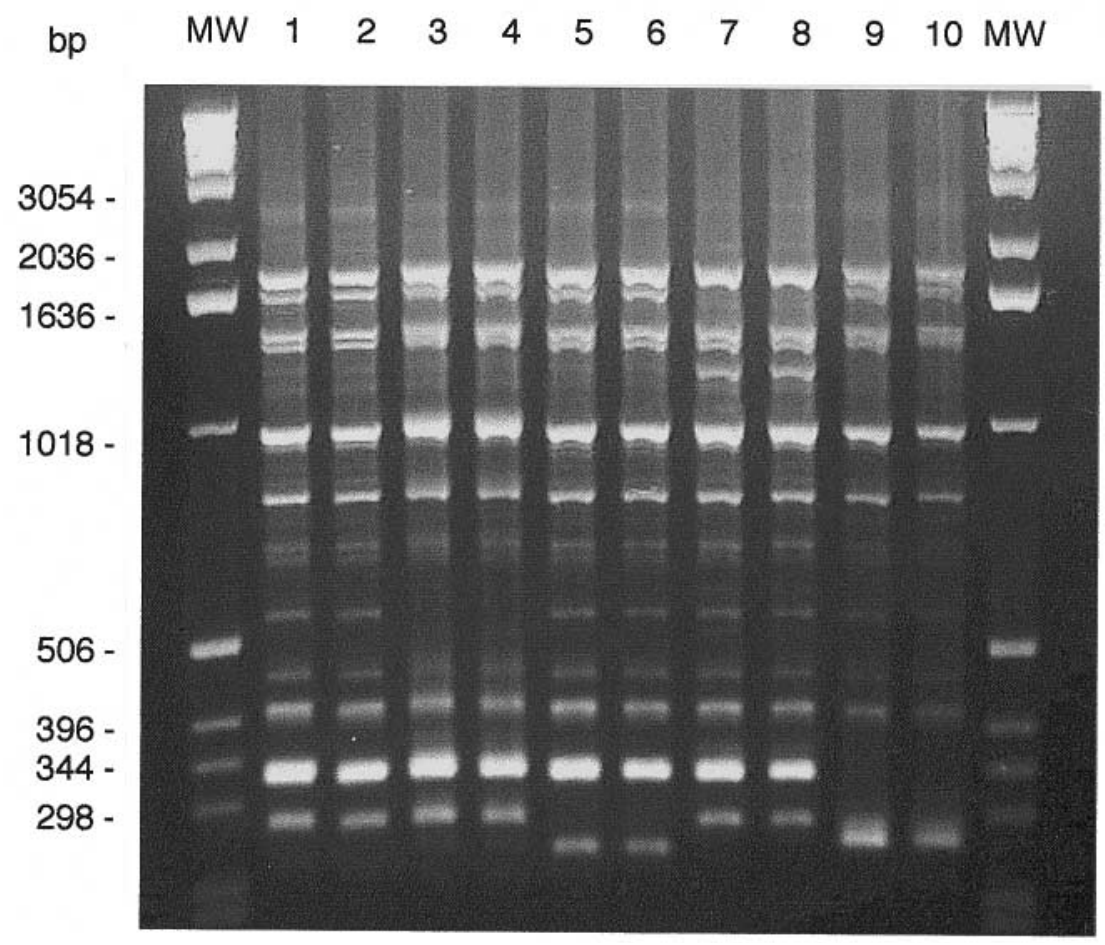

Fig. 2. Restriction endonuclease analysis of isolates 908820 and 908821 after RAPD-PCR analysis with (a) primer 1247 and (b) primer 1290. Lanes: 1, uncut 908820; 2, uncut 908821; 3, BglII 908820; 4, BglII 908821; 5, EcoRI 908820; 6, EcoRI 908821; 7, PvuI 908820; 8, PvuI 908821; 9, SmaI 908820; 10, SmaI 908821; MW, 1-kb DNA mol. wt ladder (GibcoBRL).

the primer chosen. This is demonstrated by the variation in ability to discriminate between STEC $\mathrm{O} 157$ in various studies that used different primers. Hopkins and Hilton [19] differentiated between strains of STEC O157 that also differed in phage type and Birch et al. [20] were able to discriminate between isolates that were identical in Shiga-like toxin type and phage type. However, Schmidt et al. [21] were unable 
to distinguish between the STEC O157 strains used in their study by RAPD-PCR analysis. A single primer may miss sequence changes if they do not alter or remove a primer-binding site. The use of a second, single primer may detect the sequence change and lead to a variation in the pattern of amplicons, thus increasing the discriminatory power of RAPD-PCR analysis [22]. However, optimisation of reaction conditions for RAPD-PCR with a new primer often requires alterations in the reaction and cycling conditions, which can be time-consuming [17].

It is clear from studies on the typing of STEC 0157 that methods with high levels of discrimination are undoubtedly needed in many contexts to provide the best evidence for strain identity [23]. This study demonstrates in principle the potential of REA of RAPD-PCR amplicons to reveal intra-amplicon sequence variation between strains. This may provide additional discrimination from RAPD-PCR profiles without the need to proceed with new primer(s) or other methods such as PFGE.

This work was funded by a grant provided by the Division of Environmental Health and Risk Management, University of Birmingham. STEC O157 strains were gratefully received from Dr Kathy Nye, Birmingham Public Health Laboratory, West Midlands.

\section{References}

1. Riley LW, Remis RS, Helgerson SD et al. Hemorrhagic colitis associated with a rare Escherichia coli serotype. $N$ Engl J Med 1983; 308: 681-685.

2. Anon. Vero cytotoxin producing Escherichia coli in England and Wales. CDR Weekly 2000; 2: 12.

3. Bell C, Kyriakides A. Outbreaks: causes and lessons to be learnt. In: E. coli. A practical approach to the organism and its control in foods. London, Blackie Academic \& Professional. 1998: $15-43$.

4. Griffin PM, Tauxe RV. The epidemiology of infections caused by Escherichia coli O157:H7, other enterohemorrhagic E. coli, and the associated hemolytic uremic syndrome. Epidemiol Rev 1991; 13: 60-98.

5. Parry SM, Salmon RL, Willshaw GA et al. Haemorrhagic colitis in child after visit to farm visitor centre. Lancet 1995; 346: 572 .

6. Ratnam S, March SB, Ahmed R, Bezanson GS, Kasatiya S. Characterization of Escherichia coli serotype 0157:H7. J Clin Microbiol 1988; 26: 2006-2012.

7. Ostroff SM, Tarr PI, Neill MA, Lewis JH, Hargrett-Bean N, Kobayashi JM. Toxin genotypes and plasmid profiles as determinants of systemic sequelae in Escherichia coli O157:H7 infections. J Infect Dis 1989; 160: 994-998.
8. Frost JA, Cheasty T, Thomas A, Rowe B. Phage typing of vero cytotoxin-producing Escherichia coli 0157 isolated in the United Kingdom: 1989:91. Epidemiol Infect 1993; 110: 469-475.

9. Martin IE, Tyler SD, Tyler KD, Khakrhia R, Johnson WM. Evaluation of ribotyping as an epidemiologic tool for typing Escherichia coli serogroup $\mathrm{O} 157$ isolates. J Clin Microbiol 1996; 34: 720-723.

10. Barrett TJ, Lior H, Green JH et al. Laboratory investigation of a multistate food-borne outbreak of Escherichia coli O157:H7 by using pulsed-field gel electrophoresis and phage typing. J Clin Microbiol 1994; 32: 3013-3017.

11. Grif K, Karch H, Schneider C et al. Comparative study of five different techniques for epidemiological typing of Escherichia coli O157. Diagn Microbiol Infect Dis 1998; 32: 165-176.

12. Welsh J, McClelland M. Fingerprinting genomes using PCR with arbitrary primers. Nucleic Acids Res 1990; 18 7213-7218.

13. Williams JGK, Kubelik AR, Livak KJ, Rafalski JA, Tingey SV. DNA polymorphisms amplified by arbitrary primers are useful as genetic markers. Nucleic Acids Res 1990; 18: 6531-6535.

14. Hilton AC, Penn CW. Restriction enzyme analysis of randomly amplified polymorphic DNA amplicons of Salmonella enterica ser. Enteritidis PT4 and Typhimurium DT104. Lett Appl Microbiol 1998; 27: 158-162.

15. Hilton AC, Banks JG, Penn CW. Random amplification of polymorphic DNA (RAPD) of Salmonella: strain differentiation and characterization of amplified sequences. J Appl Bacteriol 1996; 81: 575-584.

16. Akopyanz N, Bukanov NO, Westblom TU, Kresovich S, Berg DE. DNA diversity among clinical isolates of Helicobacter pylori detected by PCR-based RAPD-fingerprinting. Nucleic Acids Res 1992; 20: 5137-5142.

17. Hilton AC, Banks JG, Penn CW. Optimization of RAPD for fingerprinting Salmonella. Lett Appl Microbiol 1997; 24: $243-248$.

18. Whittam TS, Wachsmuth IK, Wilson RA. Genetic evidence of clonal descent of Escherichia coli O157:H7 associated with hemorrhagic colitis and hemolytic uremic syndrome. J Infect Dis 1988; 157: 1124-1133.

19. Hopkins KL, Hilton AC. Simultaneous molecular subtyping and shiga toxin gene detection in Escherichia coli using multiplex polymerase chain reaction. Lett Appl Microbiol 2000; 30: $122-125$

20. Birch M, Denning DW, Law D. Rapid genotyping of Escherichia coli $\mathrm{O} 157$ isolates by random amplification of polymorphic DNA. Eur J Clin Microbiol Infect Dis 1996; 15: 297-302.

21. Schmidt H, Geitz C, Tarr PI, Frosch M, Karch H. NonO157:H7 pathogenic shiga toxin-producing Escherichia coli: phenotypic and genetic profiling of virulence traits and evidence for clonality. J Infect Dis 1999; 179: 115-123.

22. Louie M, Jayaratne $\mathrm{P}$, Luchsinger I et al. Comparison of ribotyping, arbitrarily primed PCR, and pulsed-field gel electrophoresis for molecular typing of Listeria monocytogenes. J Clin Microbiol 1996; 34: 15-19.

23. Strockbine NA, Wells JG, Bopp CA, Barrett TJ. Overview of detection and subtyping methods. In: Kaper JB, O'Brien AD (eds) Escherichia coli $\mathrm{O} 157$ and other shiga toxin-producing E. coli strains. Washington, DC, American Society for Microbiology. 1998: 331-356. 